\title{
Masculinity and Femininity in Yuriko Koike's Speech Style
}

\author{
Parwati Hadi Noorsanti ${ }^{*}$ \\ ${ }^{1}$ Department of Japanese Studies, Faculty of Humanities, Universitas Airlangga, Surabaya \\ 60286, Indonesia \\ *) Corresponding Author \\ Email: n.awan@psau.edu.sa \\ DOI: 10.18326/rgt.v14i1.139-156 \\ Submission Track: \\ Received: 28-03-2021 \\ Final Revision: 28-05-2021 \\ Available Online: 08-06-2021 \\ Copyright @ 2021 Authors
}

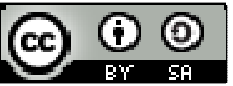

This work is licensed under a Creative Commons Attribution-ShareAlike 4.0

International License.

\begin{abstract}
This study aims at describing Yuriko Koike's speech style in conducting verbal interaction in public in relation to her profession as a politician and the Governor of Tokyo. In relation to gender stereotypes, women have a feminine speech style while men have masculine speech style. The activities as a woman politician and leader will indeed affect Yuriko Koike's language use in public communication, whether she fully incorporates a feminine style or also employs a masculine style. The data of this study is Yuriko Koike's utterances in verbal interaction taken from YouTube, comprising informal talk show, formal talk show, and press conference. The data are analyzed with the theories of gender and language, as well as speech style, proposed by Holmes and Stubbe (2003) and Talbot (2003). From the data obtained, it can be deduced that Yuriko Koike's speech style is androgynous, which combines the masculine and feminine speech styles. Her speech style, therefore, does not reflect the stereotypical style of the traditional Japanese women, which is polite, soft, unassertive, and indirect. Instead, Yuriko Koike is the depiction of the deconstruction of Japanese women's communication today, by which she shows herself as a respected leader to her political opponents. Koike generally has a communication style of a leader, that is public, report, lecturing, referentially oriented, problem-solving, dominating, and task/outcome-oriented. Specifically, her masculine speech style includes direct, competitive, independent-autonomy, and dominant, while her feminine styles were affectively oriented-sympathy, rapport, intimacy-connection, collaborative, and supportive feedback.
\end{abstract}

Keywords: speech style; feminine; masculine; Yuriko Koike 


\section{INTRODUCTION}

Japan is one of the countries with low engagement of women in politics. Reported from the news source Japan Times on January 3, 2018, entitled "Diet Bill Set to Address Low Number of Women in Japanese Politics", at the end of 2017, there was only $10,1 \%$ of women to be Diet (Japanese parliament) members at the national level. This indicates that women have not had an equal position as that of men in the political world. Moreover, Japan was ranked $121^{\text {th }}$ (with the top ten countries are Iceland, Norway, Finland, Sweden, Nicaragua, New Zealand, Ireland, Spain, Rwanda, and Germany) out of 153 countries on the 2020 Global Gender Gap Index of the World Economic Forum. The gap is the worst rank among developed countries and the score is bad in showing women's economic participation and empowerment in politics (Park \& Kim, 2021).

Several factors affecting the low number of Japanese women in politics are the culture of the Japanese community, which considers women as weak and marginal, the women's characters, family support, and household chores that cannot be abandoned (Osako, 1978; Nakano, 2013; Iwao, 1993). Besides, there are also factors from the Japanese political parties and system, such as the regulations in the parties and the electoral system, which does not support the improvement of female politicians (Kage, 2019; Dalton, 2015). Masculine traits are also considered to be more central in politics than feminine traits, particularly in the executive and national levels (Huddy \& Terkildsen, 1993), along with the cynicism of the community toward women politicians (Jinah \& Lee, 2016).

With the various obstacles that hinder Japanese women in politics, women should create some strategies to survive in the political world. One of the strategies is utilizing their communication skills. Communication skills are crucial for politicians since they need a tool to convey their thoughts, arguments, and opinions to public. Moreover, the communication tool is language, which is one of the tools for politicians to gain sympathy and support from the community. For politicians, having oral communication skills is the main requirement to attract the audience in campaigning (Cangara, 2018). Political language usually utilizes certain linguistic features to persuade the community, such as repetition as affirmation, specific terms or jargons, passive sentence 
structure, and metaphor or euphemism as meaning substitution (Mooney \& Evans, 2019). Several studies have been conducted on political language use, and Azuma's (2011) is an example. Azuma (2011) investigated the political language use of the politicians of the Democratic Party of Japan (DJP) and the Liberal Democratic Party (LDP). The results of the study are the Democratic Party of Japan tends to employ the involvement approach with the solidarity frame in its political communication while, on the contrary, the Liberal Democratic Party of Japan tends to prioritize the power frame (Azuma, 2011).

With the scarcity of female politicians in Japan, Yuriko Koike brings new expectations on the increasing number of women politicians and women working in the public environment. Yuriko Koike is the incumbent Governor of Tokyo who won the second term at the 2020 Tokyo gubernatorial election. The political positions she occupied were the Minister of the Environment in the period of Prime Minister Junichirō Koizumi and the first woman to be the Minister of Defense in the period of Prime Minister Shinzo Abe. However, she resigned after serving for only 54 days because of leaked aegis confidential information. Before involving herself in the political world in the 1990s, Koike was an Arabic translator, journalist, and news anchor in 1979 (Hidayati, 2020). Her achievements include the Female Broadcaster of Japan in 1990 and the World's 100 Most Powerful Women 2020 presented by Forbes Magazine. These achievements were presented to her due to her outstanding ability in responding to the Covid-19 spread in Tokyo, besides being a supportive leader to the SMEs. Snow (2017), a professor of the University of California, argued that Koike's triumph in becoming a reliable politician is because of her success in merging courage in politics, robust communication style, and expertise in public relations and media. Koike's slogan 'citizen first' gains sympathy from the community.

Men and women are different psychologically, hence the distinguished communication styles between them. The distinction in communication style thus generates dissimilar leadership styles between men and women (Merchant, 2012). Japanese women, meanwhile, have their stereotype in communication, including softer, more polite, more unassertive, more empathic, more cooperative, standard, and more prescriptive grammar and utterance than men's. From a linguistic perspective, Japanese women's 
language (joseigo) also has its specific features, particularly in the Standard Japanese language, such as honorifics, self-reference, greetings, sentenceending particles, indirect speech act, interjection and exclamatory expressions, and tone levels (Okamoto \& Shibamoto, 2004; Okamoto, 2004).

According to history, the rationale of distinction between Japanese women and men's languages is due to the disparity in social positions (Inoue, 2016). In the community, women are considered to have a lower position than that of men. In consequence, women who want to be regarded with the high position will acquire the polite language since-as housewives whose main role is maintaining wa (peace) -women must employ the more polite utterance (Abe, 1995). However, along with the times, language use based on gender or the gender stereotypes in the language is not visible. This is depicted in Tanaka's (2004) study, which focused on the difference in communication between Japanese men and women in the interview. The results indicated that all male and female participants demonstrated a very cooperative communication style. This style is more pronounced if there is no conflict generated from the status, age, or gender distinction. Therefore, it can be deduced that there is no "stereotypical" communication style such as "feminine" (onnarashii) or "masculine" (otokorashii) in the language use. Besides, Tanaka also suggested that gender difference in the Japanese language is less noticeable in the formal situation.

The study on female Japanese politicians was conducted by Meyner (2013), which focused on language use among female Japanese politician, in which the politicians' communication did not explicitly contain women's language use (joseigo) in their political communication. Another study was conducted by Jinah and Kwangho (2016), which investigated voter perceptions on the characters and competence of female Japanese politicians through online survey. The findings demonstrated that male politicians were considered more competent in governance issues, such as national security, trade, foreign affairs, economic policy, and political reformation, while female politicians were seen to be more capable in the welfare issue. This indicates that the respondents were still cynical about women politicians who were considered to be merely able to do the work in certain fields.

This study focuses on the language use of a female Japanese politician, namely Yuriko Koike, from a gender perspective. Therefore, this study aims at 
describing Yuriko Koike's speech style in her political communication. The speech style in questions is whether Koike only employs feminine style in her verbal interaction or also incorporates masculine style. The results of the present study are expected to provide an illustration of Japanese political condition from communication and gender perspectives.

\section{Speech Style}

The studies of gender and language are traditionally believed to be the reflection of the community's beliefs and values concerning men and women. Men and women's languages are considered to be a part of a similar discourse process in the social construction of gender (Weatherall, 2002). Principally, language and gender issues can be seen from three aspects, namely deficit, meaning that women are in the subordinate position of the community so that they tend to use hedges and other linguistic features; difference, meaning that men and women have distinct life experiences so that they speak from the different cultural perspectives; and domination, meaning that interruption and taking a turn to speak are conducted more often by men than by women (van Dijk, 1997).

There are various opinions regarding the contrast in the way men and women communicate. It is said that men use their remarks to get attention and to maintain their positions and statuses in the social hierarchy, while women employ their expressions to create rapport, to maintain their relationships, and to portray solidarity (Weatherall, 2002). Besides, Eckert and Ginet (2003) claimed that men's utterances are competitive and individualistic, while women's expressions are cooperative and other-oriented. Eckert and Ginet (2003) also cited Holmes (1995), who described gender distribution from several types of speech act. Here, Holmes (1995) argued that women are linguistically more polite than men, women praise more than men, and women apologize more often than men. In short, women conduct positive (compliment) and negative (apology) politeness more often than men do.

A conversation has the objective to express the speaker's intention toward others. The extent to which a person's meaning is properly understood depends on the extent of the conversation strategy, and hence the use of linguistic devices. Furthermore, the similarity of such devices allows the 
construction of shared meanings to create a satisfying sense of harmony that often accompanies conversations between people of identical social, ethnic, geographic, or class backgrounds (Tannen, 2005). In speech events, strategies undertaken by women are different from those by men. For instance, English women tend to emphasize more cooperative and supportive strategies than men do in speaking.

Table 1 comprises the communication styles between men and women as proposed by Holmes and Stubbe (2003). They used the words "feminine" and "masculine" to signify "women" and "men".

In addition to Holmes and Stubbe, Talbot (2003) also proposed the binary opposition to describe the distinctive characteristics of men and women in the conversational style, as presented in Table 2.

\section{Table 1}

The Masculine and Feminine Communication Styles

\begin{tabular}{ll}
\hline Feminine & Masculine \\
\hline indirect & direct \\
conciliatory & confrontational \\
facilitative & competitive \\
collaborative & autonomous \\
minor contribution (public) & dominating (in public), talking time \\
supportive feedback & aggressive interruption \\
person/process-oriented & task/outcome-oriented \\
affectively oriented & referentially oriented \\
\hline
\end{tabular}

\section{Table 2}

The Binary Opposition of Men and Women's Communication Style

\begin{tabular}{ll}
\hline Women & Men \\
\hline sympathy & problem-solving \\
rapport & report \\
listening & lecturing \\
private & public \\
connection & status \\
supportive & oppositional \\
intimacy & independence \\
\hline
\end{tabular}




\section{RESEARCH METHOD}

This study was qualitative research with the utterances stated by Yuriko Koike in verbal interaction activities as the data. The data sources were YouTube videos taken from several channels as follows:

1. Data source 1 was a video from Cafesta program entitled "(Cafesta) 自民党女性局スマイル ウーマン. Jiminto Joseikyoku一Smile Women)". Cafesta is a talk show on various themes such as politics, government policies, or the situation of Jiminto (Liberal Democratic) Party.

2. Data source 2 was a video from FCCJ Channel (日本外国特派員協会会見映像オフィシャルサイト) entitled “The Foreign Correspondent's Club of Japan 日本外国特派員協会 (にほんがいこくとくはいんきょうかい) Yuriko Koike: The state of the governor's administration and what lies ahead". This channel airs press conferences for politicians, statesmen, athletes, or public figures. In the press conference, interpreters were provided since the journalists came from various countries.

3. Data source 3 was a video from the Atlantic channel entitled "Talking Tokyo/CityLab Paris." This program was hosted by Caroline Kennedy and the interviewee was Yuriko Koike. The Atlantic is a YouTube channel that presents the world's popular experts and leaders in talk shows and directly engages the audience online.

The data sources of interview and talk show are the real illustration of verbal interaction. In verbal interaction, there are situations where a person can utter some expressions that denote their speech style to be feminine or masculine.

\section{Technique of Data Collection and Data Analysis}

The data collection was conducted using the observation method, namely uninvolved conversation observation and note-taking techniques. The uninvolved conversation observation technique was conducted since the author was not engaged in the interaction or dialogue, and the author merely observed the dialogue as a data source instead (Mahsun, 2007). The data were obtained through the following procedures: 1) downloading the talk show videos from 
YouTube; 2) observing the videos carefully; 3) transcribing the content of the interview by noting the utterances; 4) translating Japanese utterances into Indonesian; 5) marking or noting the parts of the utterances to be the data, that is the ones with backchannel, interruption, overlap, tag question, joke, and others estimated to have masculine or feminine speech style; 6) classifying the data based on the linguistic phenomena; and 7) tabulating the data by qualitatively calculating the number of linguistic phenomena from each data source.

After the data were obtained, the next step was analyzing the linguistic phenomena employing the theories of language and gender by Holmes \& Stubbe (2003) and Talbot (2003), as well as the theory of Japanese women's language variety. Theories from Holmes \& Stubbe (2003) and Talbot (2003) were employed as the foundation to categorize the utterance based on masculine or feminine style. The data classification results, thereafter, were analyzed by correlating the background or situation in the topic of the talk shows, the background of the woman figure, characteristics of the community, and, ultimately, a conclusion was then drawn from the analysis results.

\section{RESULTS AND DISCUSSION}

This section presents the discussion of Yuriko Koike's speech style seen from verbal communication in interviews aired to public. There are three data sources in this study, which were all obtained from YouTube. Table 3 is the data tabulation result based on the linguistic phenomena in Yuriko Koike's verbal utterances.

\section{Table 3}

The Data Tabulation of Yuriko Koike's Communication Style

\begin{tabular}{lccc}
\hline \multirow{2}{*}{ Linguistic Phenomena } & \multicolumn{3}{c}{ Data Sources } \\
\cline { 2 - 4 } & 1 & 2 & 3 \\
\hline backchannel & 21 & 0 & 4 \\
overlapping & 14 & 0 & 0 \\
addressing & 5 & 0 & 1 \\
joking & 4 & 0 & 2 \\
impressing & 5 & 1 & 3 \\
interruption & 2 & 1 & 1 \\
tag question & 2 & 0 & 0 \\
\hline
\end{tabular}


In Table 3, Data Source 1, 2, and 3 represent the data sources mentioned in the research methods. Data Source 1 was a semi-formal talk show since the interviewer was a person who was in the same activity environment as Koike. Then, Data Source 2 was a press conference attended by journalists from various countries, while, similar to Data Source 2, Data Source 3 was attended by numerous journalists from other countries with Caroline Kennedy as the interviewer. It can be observed from the table that the linguistic phenomena that appeared in Source Data 1 are far more frequent than other sources. It occurs since Data Source 1 was a semi-formal, casual conversation even though the topic raised was politics. Among these three sources, Data Source 2 is the most formal conversation since it was a press conference. Meanwhile, Data Source 3 was a formal talk show; there was a distance between Koike and Kennedy since the interviewer did not understand Japanese so that Kennedy needed a little more time to listen to the interpretation from the machine translation on her ears.

The different natures or genres of these data sources make the frequency of linguistic phenomena appear differently as well. An interview is different from a natural conversation since the former is controlled by the interviewer with the emphasis on the interviewee. Thus, there is an intervention from the interviewer in that the interviewee should respond following the questions asked by the interviewer (Abell \& Greg, 2008; Thomson, 2000).

Table 4

Yuriko Koike's Masculine and Feminine Speech Styles

\begin{tabular}{|c|c|c|c|}
\hline \multicolumn{2}{|c|}{ Masculine } & \multicolumn{2}{|c|}{ Feminine } \\
\hline Speech Style & Language & Speech Style & Language \\
\hline & Phenomena & & Phenomena \\
\hline direct & imperative form & $\begin{array}{l}\text { affectively oriented- } \\
\text { sympathy }\end{array}$ & impressing \\
\hline competitive & interruption & rapport & $\begin{array}{l}\text { addressing, asking, } \\
\text { joking, impressing, } \\
\text { involving }\end{array}$ \\
\hline $\begin{array}{l}\text { independent- } \\
\text { autonomy }\end{array}$ & assertive form & intimacy-connection & $\begin{array}{l}\text { addressing, asking, } \\
\text { joking, impressing, } \\
\text { involving }\end{array}$ \\
\hline dominant & $\begin{array}{l}\text { interruption, } \\
\text { overlap }\end{array}$ & collaborative & $\begin{array}{l}\text { backchannel, tag } \\
\text { question, overlap }\end{array}$ \\
\hline & & supportive feedback & $\begin{array}{l}\text { backchannel } \\
\text { (aizuchi) }\end{array}$ \\
\hline
\end{tabular}


The data analysis was not only based on the linguistic phenomena as presented in Table 3. It also illustrated other phenomena, which can depict masculine and feminine characteristics, such as humor, impressions (compliment and gratitude), as well as imperative and assertive utterances. The results are displayed in Table 4.

\section{Masculine Speech Style}

There are several types of masculine communication style Yuriko Koike had, namely direct, competitive, Independent-autonomy, and dominant. These styles are depicted in the following dialogues.

(Data 1)

Caroline Kennedy: So first of all, one of the themes of CityLab is innovation, innovative leadership and you have once been a leader in innovation, compounding Cool Biz and ....

Yuriko Koike: Oh yes Cool Biz, but maybe of them, maybe of you (the audience) have no idea about Cool Biz, would you please explain to them? (Data Source 3 (04:58)).

In high confidence, Koike interrupted Kennedy's utterance and asked her to directly describe what Cool Biz was. The imperative statement utilized to ask directly indicated that Koike had a direct communication style and did not employ any symbolization when asking someone to do something. Meanwhile, direct communication is not the stereotypical style of Japanese women (Okamoto \& Shibamoto, 2004; Okamoto, 2004). Instead, Koike employed direct speech to reflect that there are several characteristics of traditional Japanese women's communication (one of which is indirect speech) that are disadvantageous if used in political communication.

In the three interviews, Koike interrupted several times. In Data 1, Koike interrupted Kennedy and even asked Kennedy to directly explain Cool Biz to the audience, while Cool Biz is an energy-saving program carried out in Japan. Also, in the press conference, when the interpreter explained in English regarding her previous answer, Koike directly interrupted by saying, "May I ahead?" while adding information regarding the answer. Besides interruption, Koike also often did overlap particularly in Data Source 1, in which the interview was casual and the host, Michiko Ueno, was her colleague, who served as the head of Women's Affair Bureau. Since they were so close to each other, the overlap occurred most often in this interview. 
Several interruptions and overlaps that Koike undertook demonstrated domination (dominant) and competition (competitive). According to Eckert and Ginet (2003), the critical thing of overlap and interruption in a conversation is that they become an individual's tool to show their domination focusing more on the authority. Nevertheless, overlap can also be a conversation strategy by becoming something that annoys others by flaunting dominance. Meanwhile, according to Tanaka (2004), interruption can be seen from another perspective in that the interruption related to authority and domination is employed differently. In most cases, interruption depicts interest in the interaction, which, in Japanese culture, is not always a "violation."

Koike is fluent in English, yet in the press conference attended by journalists from various media all over the world, she employed Japanese instead. She did this since many Japanese journalists came to see her speak in Japanese (Data 2 and 9). On another occasion, Koike flatly refused to answer the question about her personal matters (Data 3). This indicates that she had a sense of independence from others (independent-autonomy).

(Data 2)

Yuriko Koike: Let me answer your question in Japanese, please allow me to do so. (Data Source 2 (27:30))

(Data 3)

YurikoＫoike: ありがとうございます。毎日統制のこと 忙しくて。自分自身のこと考える暇がございません。Thank you very much for your question.

(Thank you. Since I am busy working every day, I don't have much time to think about my personal matters.) (Data Source 2 (51:02))

Other types of masculine communication style in Table 3 are public, report, lecturing, referentially oriented, problem-solving, dominating, and task/outcome-oriented. In general, these characteristics can be certainly present in the dictions of politicians or leaders speaking in public. Since the context of the interviews in the data sources was public, namely press conference and talk show, the topics being raised were also general (public, problem-solving, task/outcome-oriented). Additionally, as a leader, Koike answered the questions as expected: based on references or data, in that she frequently mentioned more numbers than merely using adjectives such as "too low", "many", "excessive", "too little", and so on. She also explained the data 
systematically so that people would understand her well. Therefore, this indicates the styles of referentially oriented, report, and lecturing.

\section{Feminine Speech Style}

In Data Source 1 (Cafesta talk show), Koike gave many compliments like oishii ("delicious") and gratitude when being offered drinks and Japanese traditional snacks (inogo). Koike also frequently delivered her gratitude in answering questions in Data Source 2 and 3. Gratitude and compliment are the expressions used to show that Koike appreciated others, which is in accordance with affectively oriented sympathy of feminine communication style.

(Data 4)

Yuriko Koike: 上野さんとはね、もう前のね 3 年まえの参院選挙でねえ...

(Also, with Ms. Ueno, three years ago in the House of Councilor election...)

(Data Source 1 (02:23))

(Data 5)

Yuriko Koike: これどうやって捕まえるの?

(How to catch this?) (Data Source 1 (5:30))

(Data 6)

Yuriko Koike: なによりもやっぱりあの世界中で一番おいしいお寿司が食 ベらえるの東京ではないかと思っています、あのシンガポールからも ぜひ多くな皆さん東京にいいら去っていただきたいと思います。

(The most important thing, in my opinion, is that Tokyo is the place where you can enjoy the most delightful sushi in the world. I want many people from Singapore to come to Tokyo.) (Data Source 2 (31:20))

(Data 7)

Yuriko Koike: あの、まず2 024 にパリーでのお開催が実所が決ま ったということで、ええパリーの皆さんフランス皆さんにはおめでと ございますと申し上げたいと思います。

(First of all, I would like to express my gratitude toward all of you, France, because the actual program is decided to be held in Paris in 2024.) (Data Source 2 (33:45))

Data 4 is an example of addressing uttered by Koike. In the Cafesta talk show, Koike mentioned the host's name several times in her answers. Meanwhile, in Data 6 and 7, Koike involved the interviewers by inviting the people from Singapore to come to enjoy delicious sushi in Tokyo when being asked by a Singaporean journalist regarding the policy of the Tsukiji fish market 
in Tokyo. Also, in Data 7, Koike congratulated French citizens when being asked by a French journalist about Olympiad since the 2024 Olympiad will be held in Paris, France. Data 6 and 7 indicate that Koike attempted to involve the interlocutors deeper into the topic discussed in her answers.

Next, Data 5 illustrates Koike's appreciation toward others by showing her attention to the topic discussed. Data 5 demonstrates high involvement in the interview, which is in line with Tannen's (1994) statement that asking questions shows high involvement in the conversation. Data 4, 6, and 7 also indicate high involvement since Koike attempted to engage the interviewers in her answers. These data signal rapport-intimacy-connection of feminine communication style since Koike attempted to maintain her relations with the interlocutors and to become more familiar with them.

Moreover, backchannel occurs most frequently in Data Source 1 since this source contained casual conversation, which allows backchannel to happen. Backchannel is similar to aizuchi in Japanese, which is a response given to the interlocutor. In the source, the backchannels done by Koike were mostly hai ("yes"), sou desu ka ("is that so"), and naruhodo ("I see"). Another response in the interview was nod, as also found in Data Source 2 and 3.

Backchannel is the most important thing in conversation. Eckert and Ginet (2003) stated that it is crucial to respond when someone speaks, for instance, by nodding or giving responses or backchannel such as "yes," "really?" and so on. Backchannel in women's utterance is used to show concern, while in men's utterance, it is used to show agreement.

Then, from the perspective of women's communication style, overlap can be said to be a strategy that supports others' contribution to increasing the conversation quality instead of violating the right to speak (Tannen, 1994; Eckert \& Ginet, 2003). Overlap mostly appears in Data Source 1 since the source is a talk show. The host of the talk show, Michiko Ueno, was quite close to Koike since they were co-workers. Therefore, overlap occurred more frequently along with their laughter. This is in line with Tannen's (1994) argument that overlap mostly occurs in casual conversations.

Koike only did tag questions twice to the host. Tag questions have various functions, such as showing uncertainty and asking for confirmation (epistemic modal function). It can also mean facilitative, softening, or challenging. The use 
of tag questions reflects the speaker's attitude toward the content of the main clause and asks the interlocutor to also assist in assessing the content. A higher proportion of tag questions is uttered by women to be facilitative or mitigating (Eckert \& Ginet, 2003). Backchannel, overlap, and tag questions are classified as collaborative and supportive feedback in feminine communication style.

(Data 8)

Yuriko Koike: Are we economizing? (Data Source 3 (17:22))

(Data 9)

Yuriko Koike: Because of the Japanese media, people would like to listen to my word in Japanese, so I switch my channel to... Arabic? No... to Japanese. (Data Source 3 (04:03))

Data 8 and 9 are examples of joking or humor Koike conveyed. From the three data sources, Koike did a lot of humor or joking, which is mostly found in Data Sources 1. In the more official event, that is the talk show with Caroline Kennedy, Koike did humorous utterances twice (Data 8 dan Data 9). Data 8 occurred when the lights on the talk show were suddenly turned off and immediately turned on again, when at the same time, Koike was answering a question from an Indian journalist regarding the economy and ecology in Japan. She spontaneously said, "Are we economizing?" and being replied with laughter from the audience.

Tannen (1994) argued that humor can be seen from intonation, speed, voice quality, and non-verbal signal, by which the speaker can frame their utterances as "not meant the literal way." Sometimes humor can be utilized as sarcasm (not to be funny and to create hostility) and irony (which may cause smiles or laughter), yet its main objective is to entertain. According to Yoshida (2001), humor is one of the vehicles of power for female leaders. Women manifest who they are, what they feel, what they aim to achieve, and how to prepare themselves. Through humor, one symbolically attacks the existing order without actually ruining it.

Thus, through humor, Koike attempted to make a more intimate relationship with herself, the host, and the audience. Koike also strategized her utterances to make the communication more intimate and fluid, even though the audience is the people who rarely interact with her. Accordingly, using humor can be included in the feminine communication style of rapportintimacy-connection. 


\section{CONCLUSION}

Japanese women are characterized by being polite, soft, unassertive, empathic, cooperative, indirect, and low-voiced in communication (Okamoto \& Shibamoto, 2004; Okamoto, 2004). Meanwhile, unlike the stereotypical Japanese women, Yuriko Koike is straight to the point, assertive, clear-voiced, and confident in speaking. Even so, she also has a speech style like other Japanese women with characteristics, such as being cooperative, sympathetic, polite, and maintaining harmony in communication. Therefore, it can be said that Yuriko Koike's communication style combines the masculine and feminine communication styles (androgynous).

Koike's communication style indicates that she is an effective communicator, which is in accordance with Berko (2010), who states that the most effective communication style is androgynous, combining the quality of masculine and feminine communication styles. Communicators who opt for this style will most likely succeed effectively in certain situations since they can be flexible and adapt to any condition.[rgt]

\section{REFERENCES}

Abe, H. (1995). From stereotype to context: The study of Japanese women's speech. Feminist Studies, 21(3), 647-671. https://doi.org/10.2307/3178206

Abell, J. \& Myers, G. (2008). Analyzing research interviews. In Ruth Wodak \& Michal Krzyzanowski (eds). Qualitative discourse analysis in the social science. (pp. 145-161). New York: Palgrave Macmillan.

Azuma, S. (2011). Soapbox Speeches in the Summer of Seiken Kōtai. Japanese Language and Literature, 45(1), 141-167.

Berko, R., Aitken, J. E., Wolvin, A. (2010). Icomm Interpersonal Concept and Competencies Foundation of Interpersonal Communication. Rowman \& Littlefield Publishers. Inc.

Cafesta. 自民党女性局スマイル ウーマン. (Jiminto Joseikyoku- Smile Women).https://www.youtube.com/watch?v=0YkYWvt8b8w

Cangara, H. (2018). Komunikasi politik konsep, teori, dan strategi. Rajagrafindo Persada. 
Dalton, E. (2013). More "ordinary women": Gender stereotypes in arguments for increased female representation in Japanese Politics. U.S.-Japan Women's Journal, (44), 24-42. www.jstor.org/stable/42771844

Dubuc, C. (2012). When Women Are in Charge: The Language Japanese Women Speak at Work. Anthropologica, 54(2), 293-308. www.jstor.org/ stable/24467409

Eckert, P \& McConnel-Ginet, S. (2006). Language and Gender. Cambridge: Cambridge University Press.

Eto, M. (2016). 'Gender' problems in Japanese politics: A dispute over a sociocultural change towards increasing equality. Japanese Journal of Political Science, 17(3), 365-385. https://doi.org/10.1017/S1468109916000141

Forbes, M. \& McGrath, M. (2020). The World's 100 Most Powerful Women. https://www.forbes.com/profile/yuriko-koike/?sh=754c3bc05f7e

Hidayati, N. (2020). Yuriko Koike, gubernur perempuan pertama tokyo, terpilih lagi. https://kumparan.com/kumparannews/yuriko-koike-gubernurperempuan-pertama-tokyo-terpilih-lagi-1tkYBC5sRPD/full.

Holmes, J. (2005). Power and discourse at work: Is gender relevant? in Michelle M Lazar (ed). Feminist Critical Discourse Analysis Gender, Power, and Ideology in Discourse. (pp. 31-60). Palgrave Macmillan.

Holmes, J. \& Stubbe, M. (2003) “Feminine” Workplaces: Stereotype and Reality. In Janet Holmes \& Miriam Meyerhoff (eds). The Handbook of Language and Gender. (pp. 573-599) United Kingdom: Blackwell Publishing Ltd.

Huddy, L. \& Terkildsen, N. (1993). Gender Stereotypes and the Perception of Male and Female Candidates. American Journal of Political Science, 37(1), 119-147. doi: $10.2307 / 2111526$

Inoue, M. (2016). Where has "Japanese women's language" gone?: Notes on Language and Political Economy in the Age of Control Societies. HAU: Journal of Ethnographic Theory, 6(3), 151-177. https://doi.org/10.14318/ hau6.3.014

Iwao, S. (1993). The Japanese women: Tradisional image and changing reality. MacMillan.

Kage, R., Rosenbluth, F. \& Tanaka, S. (2019). what explains low female political representation? Evidence from survey experiments in Japan. Politics \& Gender, 15(2), 285-309. https://doi.org/10.1017/S1743923X18000223 
Klebanov, B., Diermeier, D. \& Beigman, E. (2008). Lexical cohesion analysis of political speech. Political Analysis, 16(4), 447-463.

Lee, J. \& Lee, K. (2016). Gendered reactions to women politicians in japan: the role of media use and political cynicism. Keio Communication Review, 38, 21-38.

Mashun, M. S. (2007). Metode penelitian bahasa tahapan strategi, metode, dan tekniknya. Raja Grafindo Perkasa.

Merchant, K (2012). "How men and women differ: Gender differences in communication styles, influence tactics, and leadership styles". CMC Senior Theses. Paper 513. http://scholarship.claremont.edu/cmc_theses/513

Meyner, S. (2013). Do the speechs of japanese female politicians feature Japanese women's language-political language from a gender perspective. Götenborgs Universitet Inst För Spark Och Litteraturer Japanska. (Bachelor's Thesis) https://gupea.ub.gu.se/handle/2077/35327

Mooney, A. \& Evans, B. (2019). Language, society and power an introduction. Rouledge.

Nakano, Y. (2013). Among equal? Women in Japanese politics. Center for Strategic and International Study - CSIS https://www.csis.org/analysis/japan-chairplatform-among-equals-women-japanese-politics

Okamoto, S (2004). Ideology in linguistic practice and analysis: Gender and politeness in Japanese revisited. In Shigeko Okamoto \& Janet Shibamoto (eds). Japanese Language, Gender, and Ideology. (pp. 24-38). Oxford University Press.

Okamoto, S \& Janet S. (2004). Japanese language, gender, and ideology. Oxford University Press.

Osako, M. (1978). Dilemmas of Japanese professional women. Social Problems, 26(1), 15-25. https://doi.org/10.2307/800429

Park, J-M. \& Kim, C-R. (2020). Japan's ruling party invites more women to meetings, as long as they don't talk. https://www.reuters.com/article/usjapan-politics-idUSKBN2AH08E

Snow, Nancy. (2017). Why Yuriko Koike is new face of brand Japan. The Japan Times. https://www.academia.edu/33871486/Why_Yuriko_Koike_is_the_ new_face_of_brand_Japan 
Talbolt, Mary. (2003). Gender stereotypes: Reproduction and chalenge. In Janet Holmes \& Miriam Meyerhoff (eds). The Handbook of Language and Gender. (pp. 468-489). Blackwell Publishing Ltd.

"Talking Tokyo/ CityLab Paris". https://www.youtube.com/watch?v= Ok0YN_6kqFc

Tanaka, Lidia. (2004). Language and culture (A study of Japanese television interview discourse). John Benjamins Publishing Company.

Tannen, D. (1994). Gender and discourse. Oxford University Press.

Tannen, D. (2005). Conversational style. Oxford University Press.

van Dijk, T. A. (1997). Discourse as structure and process. Sage Publications Ltd.

Weatherall, A. (2002). Gender, language and discourse. Routledge.

Wilson, J. (2001). Political Discourse. in Schiffrin, D., Tannen, D. \& Hamilton, H. E. (eds). The Handbook of Discourse Analysis. (pp. 398-415). Blackwell Publishers.

Wodak, R. (1996). Disorder of discourse. Longman

Yoshida, Mitsuhiro. (2001) Joking, Gender, Power, and Professionalism among Japanese inn workers. Ethnology 40(4), 361-369.

"Yuriko Koike: The State of the Governor's Administration and What Lies Ahead". https://www.youtube.com/watch?v=n7Gw0wqDRzw\&t=3787s 